JIPFRI, Vol. 3 No. 1 Halaman: 46-53 Mei 2019
JIPFRI (Jurnal Inovasi Pendidikan Fisika dan Riset IImiah)

https://doi.org/10.30599/jipfri.v3i1.477

\title{
Pengaruh Penerapan Model Pembelajaran Inquiry Training Terhadap Keterampilan Proses Sains Siswa SMA
}

\author{
Icha Silviana Devi ${ }^{1 *}$, Feriansyah Sesunan ${ }^{2}$, dan Ismu Wahyudi ${ }^{3}$ \\ 1,2 Prodi Pendidikan Fisika Universitas Lampung \\ Jl. Prof. Dr Soemantri Brojonegoro No. 1 Gedungmeneng Bandarlampung 35145, Indonesia \\ *E-mail: ichasilvianadevi11@gmail.com
}

\begin{abstract}
Abstrak
Penelitian ini bertujuan untuk mengetahui pengaruh penerapan model pembelajaran inquiry training terhadap keterampilan proses siswa SMA. Sampel penelitian ini di salah satu SMA Negeri di Gadingrejo, dengan desain penelitian Pretest-Posttest Control Group with non equivalent. Data diuji dengan analisis $N$-gain, uji normalitas, uji homogenitas, dan independent sample $T$-test. Hasil uji $N$-gain keterampilan proses sains pada kelas eksperimen memiliki nilai rata-rata $N$-gain 0,66 dengan kategori sedang dan pada kelas kontrol dengan kategori rendah sebesar 0,16. Hasil uji independent sample T-test nilai Sig. (2-Tailed) kurang dari 0,05, dapat disimpulkan terdapat pengaruh penerapan model pembelajaran inquiry training terhadap keterampilan proses sains siswa. Berdasarkan hasil observasi, keterampilan proses sains siswa pada kelas yang menerapkan model pembelajaran inquiry training memiliki rata-rata klasifikasi sangat baik sebanyak 23 siswa dan klasifikasi baik sebanyak 6 siswa.
\end{abstract}

Kata kunci: Pengaruh Model Pembelajaran, Inquiry Training, Keterampilan Proses Sains.

\begin{abstract}
This research aimed to find out the influence of the implementation of the inquiry training learning model on the science process skills of high school students and to find out the science process skills of students applying the inquiry training learning model. The sample of this research were in class XI IPA 1 and XI IPA 4 at a senior high school in Gadingrejo, with a pretest-posttest control group with non equivalent research design. The data were tested by $\mathrm{N}$-gain analysis, normality test, homogeneity test, and independent sample $\mathrm{T}$-test. Based on the results of $\mathrm{N}$-gain, science process skills in the experimental classes have an $\mathrm{N}$-gain average value of 0.66 with the medium category. Whereas, in the control class the $\mathrm{N}$-gain average value is 0.16 that is classified into low category. Test results for independent sample T-test Sig. (2-Tailed) is less than 0,05. It can be concluded that there is an effect of applying the inquiry training learning model on students' science process skills. Based on the results of observation, the science process skills of students in the class applying the inquiry training learning model had a very good classification of 23 students and a good classification of 6 students.
\end{abstract}

Keywords: The Influence of Learning Model, Inquiry Training, Science Process Skills

\section{PENDAHULUAN}

P21 (Partnership for 21st Century Learning) (2015) mengembangkan framework pembelajaran di abad 21, framework ini mendeskripsikan keterampilan, pengetahuan, dan keahlian yang harus dikuasai oleh siswa untuk berhasil dalam pekerjaan dan kehidupan. Setiap penerapan keterampilan abad 21 memerlukan pengembangan dari kunci pengetahuan akademik dan pemahaman di antara semua siswa. Konteks pengetahuan terdapat keterampilan penting untuk dunia saat ini, seperti mampu memecahkan masalah, berkomunikasi, dan berkolaborasi.

Peta keterampilan abad 21 menjelaskan bahwa adanya keterkaitan antara abad 21 dengan keterampilan berakar dalam hal penyelidikan (inquiry), pengetahuan proses, desain eksperimen, dan elemen kebiasaan berpikir ilmiah, seperti yang disebutkan dalam Project American Association for the Advancement of Science 2061 Benchmarks for Science Literacy, the Atlas of Science Literacy, 
dan the National Science Education Standards pada tahun 1993.

Abad 21 menuntut berbagai keterampilan, salah satunya yaitu keterampilan yang berakar dalam hal penyelidikan, maka pembelajaran saat ini harus mampu mengimplementasikan pembelajaran yang berbasis inquiry. Sesuai dengan Permendikbud Nomor 65 Tahun 2016 tentang Standar Proses, model pembelajaran inquiry adalah model pembelajaran yang diutamakan dalam implementasi kurikulum 2013 (Depdiknas, 2016).

Salah satu model pembelajaran yang berkaitan dengan hal penyelidikan yaitu model inquiry training, pada model pembelajaran ini siswa dituntut aktif mengolah pengetahuan untuk menghasilkan prinsip-prinsip, serta mengajarkan beberapa keterampilan dan berpikir ilmiah. Model pembelajaran inquiry training merupakan usaha mengembangkan para siswa yang mandiri dengan metode yang menuntut partisipasi siswa yang aktif dalam penelitian ilmiah (Sirait, 2012).

Selain itu, model inquiry training membantu siswa dalam hal penyelidikan, menyususun fakta, membentuk konsep sendiri berdasarkan percobaan, sehingga menghasilkan penjelasan atau menemukan suatu konsep yang dapat menerangkan suatu fenomena. Berkaitan dengan hal penyelidikan tentang suatu masalah yang akan dipecahkan oleh siswa, maka siswa dapat meningkatkan keterampilan proses sainsnya. Keterampilan proses sains ini merupakan kemampuan transfer konsep yang digunakan pada ilmu-ilmu sains dan diterapkan dalam pembelajaran.

Mewujudkan tujuan pendidikan di Indonesia pada abad ke-21 merupakan sebuah tantangan besar karena faktanya terdapat masalah di dalam dunia pendidikan Indonesia, salah satunya adalah lemahnya proses pembelajaran, khususnya pembelajaran fisika. Pembelajaran fisika bagi siswa dilakukan sebagai bentuk menumbuhkan keterampilan memecahkan masalah yang terkait dengan gejala atau fenomena yang terjadi di alam semesta, terutama yang terjadi di lingkungan kehidupan sehari-hari. Namun pada prosesnya siswa kurang dilatih untuk mengembangkan keterampilan proses sains dalam proses pembelajaran. Hal ini ditunjukkan dari hasil wawancara peneliti dengan guru fisika di SMA Negeri 2 Gadingrejo menunjukkan bahwa terdapat banyak siswa yang mengalami kesulitan dalam memahami dan menelaah konsep fisika pada materi-materi tertentu yang dikaitkan dengan pemecahan soal-soal fisika, padahal kurikulum 2013 menuntut siswa agar mendapat pengalaman belajar melalui pendekatan saintifik yang seharusnya siswa lebih memahami konsep yang diajarkan.

Kurang mampunya siswa dalam mengamati, manafsirkan, mengajukan petanyaan, berhipotesis, merencanakan percobaan, dan berkomunikasi pun menjadi alasan siswa mengalami kesulitan memahami konsep dan tidak berkembangnya keterampilan proses sains. Didukung dengan penelitian Bahri (2008), yang menyatakan bahwa banyak terjadi kesulitan siswa memahami bentuk soal yang diubah meski dalam konsep yang sama, hal ini berarti mengindikasikan siswa tidak memahami konsep yang sebenarnya. Oleh karena itu, penulis telah melakukan penelitian yang berjudul "Pengaruh Penerapan Model Pembelajaran Inquiry Training Terhadap Keterampilan Proses Sains Siswa SMA".

\section{METODE/EKSPERIMEN}

Desain penelitian yang digunakan dalam penelitian ini adalah quasi experiment design dengan bentuk pretest-posttest control group with non-equivalent. Secara diagram rancangan penelitian ini digambarkan pada Gambar 1.

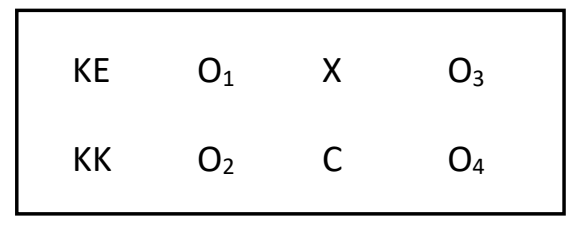

Gambar 1. Pretest-posttest control group design with non-equivalent

Penelitian ini dilakukan pada dua kelas, yaitu kelas eksperimen (KE) yang menerapkan model pembelajaran inquiry training $(\mathrm{X})$ dengan obeservasi kemampuan awal berupa pretest kelas eksperimen $\left(\mathrm{O}_{1}\right)$ dan observasi 
kemampuan akhir kelas eksperimen $\left(\mathrm{O}_{3}\right)$, sedangkan kelas kontrol (KK) yang menerapkan model pembelajaran konvensional (C) dengan obeservasi kemampuan awal berupa pretest kelas kontrol $\left(\mathrm{O}_{2}\right)$ dan observasi kemampuan akhir kelas kontrol $\left(\mathrm{O}_{4}\right)$.

Adanya observasi kemampuan awal $\left(\mathrm{O}_{1}\right.$ dan $\mathrm{O}_{2}$ ) pada kedua kelas dapat digunakan sebagai dasar dalam menentukan perubahan. Sedangkan diadakannya observasi kemampuan akhir $\left(\mathrm{O}_{3}\right.$ dan $\left.\mathrm{O}_{4}\right)$ pada akhir kegiatan akan dapat menunjukkan seberapa jauh akibat yang muncul setelah diberikan perlakuan $(X, C)$.

Populasi penelitian ini, yaitu seluruh siswa kelas XI IPA SMA Negeri 2 Gadingrejo di Kabupaten Pringsewu tahun ajaran 2018/2019. Teknik sampling yang digunakan dalam penelitian ini adalah nonprobability sampling. Adapun teknik sampel ini adalah purposive sampling. Pengambilan sampel dilakukan dengan cara memilih dua kelas dari empat kelas XI IPA yang ada di SMA Negeri 2 Gadingrejo.

Penelitian ini dilakukan pada kelas yang memiliki waktu belajar yang sama, materi belajar yang sama, dan sampel dianggap homogen atau relatif homogen, serta rata-rata hasil belajar siswa yang sama atau relatif sama pada semester sebelumnya, jika tidak ada ratarata hasil belajar siswa yang sama maka diambil beberapa hasil belajar siswa yang relatif sama dalam setiap kelas eksperimen dan kelas kontrol.

Variabel pada penelitian ini terdapat dua, yaitu variabel bebas dan variabel terikat. Variabel bebas dalam penelitian ini adalah model pembelajaran inquiry training, sedangkan variabel terikatnya adalah keterampilan proses sains.

Data yang diperoleh dalam penelitian ini adalah data kuantitatif yaitu data yang diperoleh berdasarkan nilai pretest dan posttest yang dilakukan diawal dan diakhir pembelajaran, serta data observasi langsung saat pembelajaran. Pengumpulan data dilakukan menggunakan teknik tes berupa 10 soal uraian dan teknik observasi berupa lembar observasi keterampilan proses sains.
Setelah data diperoleh, dilakukan uji analisis data berupa uji $\mathrm{N}$-gain, kemudian dilakukan uji normalitas dengan menggunakan uji statistik non-parametrik yaitu KolmogorovSmirnov untuk mengetahui data berdistribusi normal atau tidak. Mengetahui varian dalam populasi homogen atau tidak dilakukan uji homogenitas. Hasil uji homogenitas selanjutnya akan diigunakan dalam pengujian hipotesis menggunakan independent sample $T$ test.

\section{HASIL DAN PEMBAHASAN}

Penelitian ini menggunakan model pembelajaran inquiry training di kelas eksperimen dan model pembelajaran konvensional di kelas kontrol pada materi kalor mulai dilaksanakan pada tanggal 24 Januari 2019 dan berakhir pada tanggal 8 Februari 2019 di SMA Negeri 2 Gadingrejo. Pembelajaran berlangsung selama 3 kali tatap muka dengan alokasi waktu 6 jam pelajaran yang terdiri atas 45 menit pada setiap jam pelajarannya. Hasil yang diperoleh dari penelitian ini berupa data kuantitatif dari keterampilan proses sains yang selanjutnya diolah dengan menggunakan SPSS versi 21.0.

\section{HASIL}

Proses pembelajaran dilakukan dengan menerapkan model pembelajaran inquiry training di kelas eksperimen yaitu kelas XI IPA 1 dan menerapkan pembelajaran konvensional di kelas kontrol yaitu kelas XI IPA 4. Guru terlebih dahulu memberikan soal pretest kepada kedua kelas untuk menilai kemampuan awal yang dimiliki pada materi kalor di awal pembelajaran. Akhir pembelajaran dilakukan posttest untuk mengetahui sejauh mana siswa memahami dan mengerti materi yang sudah diajarkan.

Sebelum melakukan penelitian, soal terlebih dahulu diuji coba pada siswa kelas XII IPA 1 yang berjumlah 33 siswa yang telah belajar materi kalor. Instrumen soal terdiri dari 10 soal uraian. Berdasarkan uji validitas dan reliabilitas, dinyatakan terdapat 7 soal yang valid dan bersifat reliabel. Soal-soal yang valid dan reliabel inilah yang digunakan sebagai pretest-posttest keterampilan proses sains. 
Data kuantitatif yang diperoleh yaitu terdiri dari hasil pretest dan posttest keterampilan proses sains. Rata-rata hasil pretest ditunjukkan pada tabel 1, sedangkan rata-rata hasil posttest ditunjukkan pada tabel 2.

Tabel 1. Data hasil pretest siswa

\begin{tabular}{ccccc}
\hline \multirow{2}{*}{ Kelas } & \multirow{2}{*}{ Frekuensi } & \multicolumn{2}{c}{ Nilai } & $\begin{array}{c}\text { Rata- } \\
\text { rata } \\
\text { Nilai }\end{array}$ \\
\cline { 3 - 5 } & & Terendah & Tertinggi & \\
\hline Eksperimen & 29 & 10,71 & 71,43 & 33,37 \\
\hline Kontrol & 29 & 28,57 & 53,57 & 41,50 \\
\hline
\end{tabular}

Tabel 2. Data hasil posttest siswa

\begin{tabular}{ccccc}
\hline \multirow{2}{*}{ Kelas } & \multirow{2}{*}{ Frekuensi } & \multicolumn{2}{c}{ Nilai } & $\begin{array}{c}\text { Rata- } \\
\text { rata } \\
\text { Nilai }\end{array}$ \\
\cline { 3 - 4 } & Terendah & Tertinggi & \\
\hline Eksperimen & 29 & 60,71 & 92,86 & 78,08 \\
\hline Kontrol & 29 & 39,29 & 67,86 & 51,11 \\
\hline
\end{tabular}

Berdasarkan data pada tabel 1 rata-rata nilai pretest kelas eksperimen lebih kecil dari rata-rata nilai kelas kontrol, namun perbedaan rata-rata ini tidak begitu jauh. Kemudian berdasarkan data tabel 2 rata-rata nilai posttest kelas eksperimen lebih besar daripada ratarata nilai posttest kelas kontrol. Perbedaan rata-rata ini cukup jauh.

Peningkatan keterampilan proses sains siswa dapat dilihat dari selisih antara hasil pretest atau tes sebelum diberi perlakuan dengan hasil posttest atau tes setelah diberi perlakuan. Rata-rata $\mathrm{N}$-gain keterampilan proses sains siswa ditampilkan pada Tabel 3.

Tabel 3. Rata-rata $\mathrm{N}$-gain keterampilan proses sains siswa

\begin{tabular}{cccccc}
\hline \multirow{2}{*}{ Kelas } & \multicolumn{2}{c}{ Gain } & \multicolumn{2}{c}{ Rata-rata } & \\
\cline { 2 - 5 } & Tertinggi & Terendah & Gain & $\begin{array}{c}\mathbf{N} \text { - } \\
\text { gain }\end{array}$ & \\
\hline $\begin{array}{c}\text { Eksperi- } \\
\text { men } \\
\text { Kontrol }\end{array}$ & 75,00 & 17,85 & 44,70 & 0,66 & Sedang \\
& 25,00 & 0,00 & 9,61 & 0,16 & Rendah \\
\hline
\end{tabular}

Berdasarkan data pada tabel 3 dapat diketahui bahwa rata-rata peningkatan keterampilan proses sains pada kelas eskperimen lebih tinggi dari peningkatan keterampilan proses sains pada kelas kontrol.
Kriteria peningkatan $\mathrm{N}$-gain dapat kita bandingkan dengan melihat tabel 4 .

Tabel 4. Data Kategori N-gain Keterampilan Proses Sains

\begin{tabular}{lcccc}
\hline Kriteria & \multicolumn{2}{c}{ Kelas Eksperimen } & \multicolumn{2}{c}{ Kelas Kontrol } \\
& Frekuensi & Persentase & Frekuensi & Persentase \\
\hline Tinggi & 14 & $48,28 \%$ & 0 & $00,00 \%$ \\
Sedang & 15 & $51,72 \%$ & 5 & $17,24 \%$ \\
Rendah & 0 & $00,00 \%$ & 24 & $82,76 \%$ \\
\hline
\end{tabular}

Setelah didapatkan skor penilaian siswa, peneliti melakukan uji normalitas terhadap perolehan pretest dan posttest siswa untuk mengetahui apakah sampel penelitian berdistibusi normal atau tidak. Hasil uji normalitas nilai Asymp. Sig (2-tailed) pada kedua kelas lebih dari 0,05 yaitu 0,504 di kelas eksperimen dan 0,876 di kelas kontrol, maka data berdistribusi normal.

Setelah uji normalitas, dilakukan uji homogenitas untuk mengetahui apakah varian data adalah sama atau tidak. Uji ini dilakukan menggunakan Homogeneity of Variances pada One Way Anova. Variabel yang diuji homogenitasnya adalah $\mathrm{N}$-gain rata-rata dari masing-masng kelas. Hasil homogenitasnya dapat ditampilkan pada tabel 5 .

Tabel 5. Hasil Uji Homogenitas $N$-gain

\begin{tabular}{cccc}
\hline $\begin{array}{c}\text { Levene } \\
\text { Statistic }\end{array}$ & $d f 1$ & $d f 2$ & Sig. \\
\hline 0,117 & 1 & 56 & 0,733 \\
\hline
\end{tabular}

Setelah diperoleh data yang normal dan homogen berdasarkan skor $\mathrm{N}$-gain dari kelas eksperimen dan kontrol, maka data tersebut selanjutnya dapat digunakan untuk syarat pengujian dua sampel bebas menggunakan Independent Sample T-test untuk mengetahui ada tidaknya perbedaan rata-rata keterampilan proses sainns siswa sebelum dan sesudah dilakukan pembelajaran pada masing-masing kelas eksperimen dan kelas kontrol. Adapun yang diuji adalah perbedaan rerata $\mathrm{N}$-gain dari masing-masing kelas eksperimen. Hasil Uji Independent Sample T-test ditampilkan pada tabel 6 . 
Tabel 6. Hasil Uji Independent Sample T-test

\begin{tabular}{|c|c|c|c|}
\hline & & \multicolumn{2}{|c|}{ Gain } \\
\hline & & $\begin{array}{c}\text { Equal } \\
\text { Variances } \\
\text { Assumed }\end{array}$ & $\begin{array}{c}\text { Equal } \\
\text { Variance } \\
\text { s Not } \\
\text { Assumed }\end{array}$ \\
\hline $\begin{array}{l}\text { Levene's Test } \\
\text { For }\end{array}$ & $\mathrm{F}$ & 0,117 & \\
\hline $\begin{array}{l}\text { Equality Of } \\
\text { Variances }\end{array}$ & Sig & 0,733 & \\
\hline t-test for equality & $\mathrm{T}$ & $-15,383$ & $-15,383$ \\
\hline of Means & Df & 56 & 55,791 \\
\hline & $\begin{array}{l}\text { Sig. }(2- \\
\text { tailed) }\end{array}$ & 0,000 & 0,000 \\
\hline
\end{tabular}

Berdasarkan tabel 5 diperoleh nilai Sig. (2-tailed) sebesar 0,000 <0,05, maka sesuai pengambilan keputusan dalam independent sample $t$-test dapat disimpulkan bahwa $\mathrm{H}_{0}$ ditolak dan $\mathrm{H}_{1}$ diterima, yang artinya bahwa terdapat perbedaan rata-rata keterampilan proses sains siswa kelas eksperimen dan kelas kontrol secara siginifikan. Artinya model pembelajaran inquiry training memberikan pengaruh yang siginifikan terhadap keterampilan proses sains siswa.

Selain melakukan tes untuk melihat keterampilan proses sains siswa, dilakukan observasi langsung untuk mengamati keterampilan proses sains siswa yang muncul selama proses pembelajaran berlangsung. Lembar observasi berisi 19 indikator yang mewakili 6 aspek penilaian keterampilan proses sains. Hasil observasi keterampilan proses sains pada kelas eksperimen dan kelas kontrol, ditampilkan pada tabel 7.

Tabel 7. Hasil Observasi Keterampilan Proses Sains

\begin{tabular}{|c|c|c|c|c|c|c|c|c|}
\hline \multirow[b]{3}{*}{ Klasifikasi } & \multicolumn{8}{|c|}{ Frekunsi } \\
\hline & \multicolumn{4}{|c|}{ Kelas Eksperimen } & \multicolumn{4}{|c|}{ Kelas Kontrol } \\
\hline & $\begin{array}{c}\text { Tatap } \\
\text { Muka } \\
1\end{array}$ & $\begin{array}{c}\text { Tatap } \\
\text { Muka } \\
2\end{array}$ & $\begin{array}{c}\text { Tatap } \\
\text { Muka } \\
3\end{array}$ & $\begin{array}{l}\text { Rata- } \\
\text { rata }\end{array}$ & $\begin{array}{c}\text { Tatap } \\
\text { Muka } \\
1\end{array}$ & $\begin{array}{c}\text { Tatap } \\
\text { Muka } \\
2\end{array}$ & $\begin{array}{c}\text { Tatap } \\
\text { Muka } \\
3\end{array}$ & $\begin{array}{c}\text { Rata- } \\
\text { rata }\end{array}$ \\
\hline Sangat Baik & 20 & 23 & 25 & 23 & 0 & 0 & 0 & 0 \\
\hline Baik & 9 & 6 & 4 & 6 & 0 & 0 & 0 & 0 \\
\hline Kurang Baik & 0 & 0 & 0 & 0 & 6 & 6 & 5 & 6 \\
\hline Tidak Baik & 0 & 0 & 0 & 0 & 23 & 23 & 24 & 23 \\
\hline
\end{tabular}

Berdasarkan tabel 7 hasil observasi keterampilan proses sains siswa yang muncul saat pembelajaran berlangsung pada kelas yang menerapkan model pembelajaran inquiry training memiliki rata-rata klasifikasi sangat baik dan baik, sedangkan pada kelas kontrol yang menerapkan model pembelajaran konvensional memiliki rata-rata-rata klasifikasi kurang baik siswa dan tidak baik. Persentase aspek keterampilan proses sains ditampilkan pada tabel 8.

Tabel 8. Persentase aspek keterampilan proses sains

\begin{tabular}{|c|c|c|c|c|c|c|c|c|}
\hline \multirow{3}{*}{ Aspek KPS } & \multicolumn{8}{|c|}{ Persentase (\%) } \\
\hline & \multicolumn{3}{|c|}{ Tatap Muka Kelas Eksperimen } & \multirow{2}{*}{ Rata-rata } & \multicolumn{3}{|c|}{ Tatap Muka Kelas Kontrol } & \multirow{2}{*}{ Rata-rata } \\
\hline & 1 & 2 & 3 & & 1 & 2 & 3 & \\
\hline Mengamati (observasi) & 86 & 91 & 90 & 89 & 74 & 74 & 79 & 75,67 \\
\hline Mengajukan Pertanyaan & 67 & 54 & 62 & 61 & 26 & 26 & 46 & 32,67 \\
\hline Berhipotesis & 71 & 91 & 91 & 84,33 & 19 & 38 & 52 & 36,33 \\
\hline Merencana-kan Percobaan & 89 & 91 & 96 & 92 & 0 & 0 & 0 & 0 \\
\hline Menafsirkan (Interpretasi) & 80 & 94 & 94 & 89,33 & 0 & 0 & 0 & 0 \\
\hline Berkomuni-kasi & 85 & 78 & 88 & 83,67 & 0 & 0 & 0 & 0 \\
\hline
\end{tabular}


Berdasarkan tabel 8 dari seluruh aspek keterampilan proses sains yang diobservasi, seperti aspek mengamati, mengajukan pertanyaan, berhipotesis, merencanakan percobaan, menafsirkan (interpretasi), dan berkomunikasi, perbandingan rata-rata persentase antara kelas eksperimen lebih besar dibandingkan dengan kelas kontrol.

\section{PEMBAHASAN}

Rata-rata nilai tes uraian keterampilan proses sains diambil sebelum dan sesudah diterapkannya pembelajaran menggunakan model pembelajaran inquiry training dan pembelajaran menggunakan model konvensional. Pada kelas eksperimen, ratarata nilai keterampilan proses sains sebelum diterapkan pembelajaran dengan model pembelajaran inquiry training hanya sebesar 33,37, setelah diberikan perlakuan keterampilan proses sains siswa meningkat menjadi 78,08 . Terjadi peningkatan rata-rata nilai keterampilan proses sains siswa sebesar 44,41 .

Hal yang sama terjadi pada kelas kontrol, pada kelas kontrol rata-rata keterampilan proses sains siswa sebelum berlangsungnya pembelajaran hanya sebesar 41,50 , setelah diterapkan pembelajaran konvensional ratarata kemampuan berpikir kritis nya meningkat menjadi 51,11 . Terjadi peningkatan rata-rata peningkatan keterampilan proses sains siswa sebesar 9,61.

Terdapat perbedaan rata-rata keterampilan proses sains siswa pada kelas eksperimen dan kelas kontrol secara signifikan yang ditunjukkan oleh hasil uji hipotesis menggunakan uji Independent Sample T- test, dimana rata-rata $\mathrm{N}$-gain keterampilan proses sains kelas eksperimen lebih tinggi dibandingkan rata-rata $\mathrm{N}$-gain keterampilan proses sains kelas kontrol. Hal ini dapat terlihat berdasarkan hasil perhitungan rata-rata $\mathrm{N}$-gain kelas eskperimen sebesar 0,66 dengan kategori cukup.

Sedangkan pada kelas kontrol rata-rata $\mathrm{N}$-gain keterampilan proses sains siswa sebesar 0,16 dengan kategori rendah, hal ini dapat dilihat pada tabel 10 . Artinya terdapat pengaruh yang signifikan dari penerapan model pembelajaran inquiry training terhadap keterampilan proses sains siswa. $\mathrm{N}$-gain keterampilan proses sains siswa diperoleh dari data hasil penggunaan instrumen tes berupa pretest dan posttest.

Kelas eskperimen memiliki $\mathrm{N}$-gain keterampilan proses sains lebih tinggi dibanding dengan kelas kontrol. Berdasarkan hasil perhitungan diketahui bahwa pada kelas eksperimen, siswa yang memperoleh kategori tinggi sebanyak 14 siswa $(48,28 \%)$, kategori sedang 15 siswa $(51,72 \%)$, dan 0 siswa $(0,00 \%)$ yang memperoleh kategori rendah. Sedangkan pada kelas kontrol, siswa yang memperoleh kategori tinggi sebanyak 0 siswa $(00,00 \%)$, ketegori sedang 5 siswa $(17,24 \%)$, dan siswa yang mendapatkan kategori rendah sebanyak 24 siswa $(82,76 \%)$.

Hasil observasi mengenai keterampilan proses sains siswa yang muncul saat pembelajaran berlangsung, rata-rata persentase setiap aspek keterampilan proses sains yang diamati pada kelas eksperimen lebih besar dibandingkan pada kelas kontrol.

Diketahui bahwa di kelas eksperimen rata-rata persentase aspek keterampilan proses sains yang muncul saat pembelajaran berlangsung seperti mengamati (observasi) $89 \%$, mengajukan pertanyaan $61 \%$, berhipotesis $84,33 \%$, merencanakan percobaan 92\%, menafsirkan (interpretasi) $89,33 \%$, dan berkomunikasi 83,67\%. Sedangkan di kelas kontrol, aspek keterampilan proses sains seperti mengamati (observasi) $75,67 \%$, mengajukan pertanyaan $32,67 \%$, berhipotesis $36,33 \%$, merencanakan percobaan $0 \%$, menafsirkan (interpretasi) $0 \%$, dan berkomunikasi $0 \%$.

Perbedaan nilai rata-rata keterampilan proses sains pada kelas eksperimen dan kelas kontrol dapat diamati dari bagaimana proses guru dalam menyampaikan materi pembelajaran kepada siswa. Pada kelas eksperimen guru menerapkan model pembelajaran inquiry training. Model pembelajaran inquiry training ini mengedepankan konteks permasalahan untuk mengembangkan keterampilan-keterampilan kognitif dan juga membantu siswa dalam 
penyelidikan, penyusunan fakta, membentuk konsep sendiri, kemudian menghasilkan penjelasan atau menemukan suatu konsep yang dapat menerangkan suatu fenomena yang terjadi di alam semesta.

Melalui penyelidikan inilah yang melatihkan keterampilan psikomotor siswa dan mendorong siswa memiliki keterampilan proses sains. Hal ini didukung oleh hasil penelitian Prasetiyanti, dkk. (2014), yaitu bahwa pada pelaksanaan penelitian tindakan kelas dengan penggunaan metode training inquiry model dengan bantuan $K W L$ Chart pada mata kuliah konstruksi bangunan gedung mahasiswa program studi Pendidikan Teknik Bangunan Universitas Sebelas Maret dapat meningkatkan pencapaian mahasiswa dari segi aspek kognitif, afektif, dan psikomotor. Jadi, peningkatan pencapaian pembelajaran dari segi aspek kognitif, afektif, dan psikomotor dapat meningkat disebabkan adanya penerapan model pembelajaran inquiry training.

Model pembelajaran inquiry training menjadikan siswa aktif dalam proses pemecahan masalah melalui eksperimen dan dapat meningkatkan keterampilanketerampilan sains, seperti hasil penelitian yang dilakukan oleh Nurrauf, dkk. (2018) yaitu bahwa model pembelajaran inquiry training mampu melatih siswa dalam proses kerja sains/ilmiah, model pembelajaran training inquiry juga dapat menciptakan suasana belajar yang menarik sehingga memacu semangat siswa dalam belajar. Jadi, dengan pembelajaran inquiry training siswa terpacu untuk semangat belajar sehingga dapat meningkatkkan proses kerja sains.

Ditinjau dari hasil tes yang dilakukan sesudah pembelajaran, kelas yang menerapkan model pembelajaran inquiry training lebih tinggi hasil belajarnyanya dibandingkan kelas yang menerapkan pembelajaran konvensional. Hal ini didukung dengan hasil penelitian yang didukung oleh Kurniawati, dkk. (2014) menyatakan bahwa terdapat adanya perbedaan kemampuan berpikir kritis siswa antara pembelajaran inkuiri dengan pembelajaran konvensional, dengan menerapkan pembelajaran inkuiri lebih tinggi daripada menerapkan pembelajaran konvensional. Kemudian hasil penelitian Purwanto dan Mawaddah (2015) menyatakan bahwa hasil belajar siswa pada materi pokok kalor dan perpindahan kalor dengan menggunakan model pembelajaran inquiry training lebih baik dari hasil belajar siswa yang menggunakan model pembelajaran konvensional.

\section{PENUTUP}

Terdapat pengaruh penerapan model pembelajaran inquiry training terhadap keterampilan proses sains siswa, dibuktikan dengan adanya perbedaan rata-rata hasil pretest dan posttest siswa yang signifikan sehingga menghasilkan nilai $\mathrm{N}$-gain sebesar 0,66 dengan kategori sedang. Kemudian terdapat pengaruh yang signifikan penerapan model pembelajaran inquiry training terhadap keterampilan proses sains siswa yang ditunjukkan oleh hasil dari uji nilai Independent Sample T-test dengan nilai Sig. (2-Tailed) kurang dari 0,05 . Berdasarkan hasil observasi, keterampilan proses sains siswa pada kelas yang menerapkan model pembelajaran inquiry training diklasifikasikan rata-rata sangat baik sebanyak 23 siswa dan rata-rata klasifikasi baik sebanyak 6 siswa.

Berdasarkan hasil penelitian yang telah dilakukan, peneliti memberi saran supaya pembelajaran menggunakan model pembelajaran inquiry training dapat berjalan dengan lancar, yang harus disiapkan adalah perencanaan alokasi waktu dengan tepat, perangkat pembelajaran (silabus dan rencana perencanaan pembelajaran), serta media pembelajaran yang mendukung pembelajaran inquiry training saat di ruang kelas maupun di ruang laboratorium seperti lembar kerja peserta didik (LKPD), media presentasi (power point), sumber-sumber belajar siswa, dan alat-alat praktikum.

Pada pembelajaran inquiry training ditemukan ada beberapa siswa yang mengalami kesulitan dalam merumuskan masalah, masalah seperti ini akan menghambat pada sintaks penyajian masalah dalam pembelajaran inquiry training, untuk itu 
perlu diberikan orientasi masalah yang lebih jelas dan terarah, serta guru harus aktif membimbing dan mengarahkan siswa ke permasalahan yang akan dipecahkan sehingga siswa dapat berhipotesis yang sesuai dengan permasalahan yang ada.

\section{UCAPAN TERIMA KASIH}

Ucapan terimakasih ditujukan peneliti kepada kepala sekolah beserta guru-guru dan staff tata usaha SMAN 2 Gadingrejo yang telah mengizinkan, mengarahkan dan mempermudah peneliti pada saat melaksanakan penelitian, serta kepada siswasiswi yang telah membantu peneliti dalam proses pembelajaran. Ucapan terimakasih juga ditujukan peneliti kepada tim reviewer jurnal JIPFRI (Jurnal Inovasi Pendidikan Fisika dan Riset IImiah) yang telah menelaah dan mengulas artikel peneliti.

\section{DAFTAR PUSTAKA}

American Associaation for the Advancement of Science Project 2061. 1993. Benchmarks for Science Literacy. New York: Oxford University Press.

Bahri, S. (2008). Pembelajaran Fisika Berbasis Filsafat Konstruktivisme. Jurnal Pendidikan Serambi IImu, 6(1), 52-57. http://eprints.uny.ac.id/9529/5/7.\%20Daftar \%20Pustaka.pdf

Depdiknas. (2016). Permendikbud No. 65 Tahun 2016 tentang Standar Proses. Jakarta: Depdikbud.

Kurniawati, I. D., Wartono, dan Diantoro, M. (2014). Pengaruh Pembelajaran Inkuiri Terbimbing Integrasi Peer Instruction Terhadap Penguasaan Konsep Dan Kemampuan Berpikir Kritis Siswa. Jurnal Pendidikan Fisika Indonesia, 10(1): 44. http://journal.unnes.ac.id/nju/index.php/ipfi

Nurrauf, L., Nurlaelah, I. dan Setiawati I. (2018). Penerapan Model Pembelajaran Inquiry Training Terhadap Keterampilan Berpikir Kritis. Quagga, 10(2), 39-40. https://unm.ac.id/
Partnership for 21st Century Learning. (2015). Framework for $21^{\text {st }}$ Century Learning. Battelle for Kids. Diambil dari http://www.p21.org/storage/documents/doc s/P21 framework Definition New Logo 2 015.pdf

Prasetiyanti, T., Sutrisno dan Rahmawati, A. (2014). Pembelajaran Training Inquiry Model dengan Bantuan KWL Chart Terhadap Hasil Belajar Mahasiswa Pendidikan Teknik Bangunan Universitas Sebelas Maret Dalam Mata Kuliah Konstruksi Bangunan Gedung. Jurnal Pendidikan Fisika, 4(4), 114.

www.jurnal.fkip.uns.ac.id/index.php/ptb/arti cle/view/3349/2349

Purwanto dan Mawaddah A. M. (2015). Pengaruh Model Pembelajaran Inquiry Training Terhadap Hasil Belajar Fisika Siswa. Jurnal Ikatan Alumni Fisika Universitas Negeri Medan, 1(1), 42-49. https://jurnal.unimed.ac.id/2012/index.php/i npafi/index

Sirait, R. (2012). Pengaruh Model Pembelajaran Inquiry Training Terhadap Hasil Belajar Siswa pada Materi Pokok Usaha dan Energi Kelas VII MTS N-3 Medan. Jurnal Pendidikan Fisika, 1(1), 23. http://jurnal.unimed.ac.id/2012/index.php/ii af/article/view/4371 